\title{
Determinants of Catalan Public Primary Care Professionals' Intention to Use Digital Clinical Consultations (eConsulta) in the Post-COVID-19 Context: Mixed Methods Study
}

Francesc Saigí-Rubió $^{1,2}, \mathrm{PhD}$; Josep Vidal-Alaball ${ }^{3,4,5}, \mathrm{MD}, \mathrm{MPH}, \mathrm{PhD}$; Joan Torrent-Sellens ${ }^{2,6}, \mathrm{MSc}, \mathrm{PhD}$; Ana Jiménez-Zarco ${ }^{2,6}$, MSc, PhD; Francesc López Segui ${ }^{7,8}$, MSc, PhD; Marta Carrasco Hernandez ${ }^{9}$, MSc; Xavier Alzaga Reig $^{10}$, MD; Josep Maria Bonet Simó ${ }^{8}$, MD; Mercedes Abizanda González ${ }^{10,11}$, BSc; Jordi Piera-Jimenez ${ }^{12,13,14}$, MSc; Oscar Solans ${ }^{10,12}$, MD, MSc

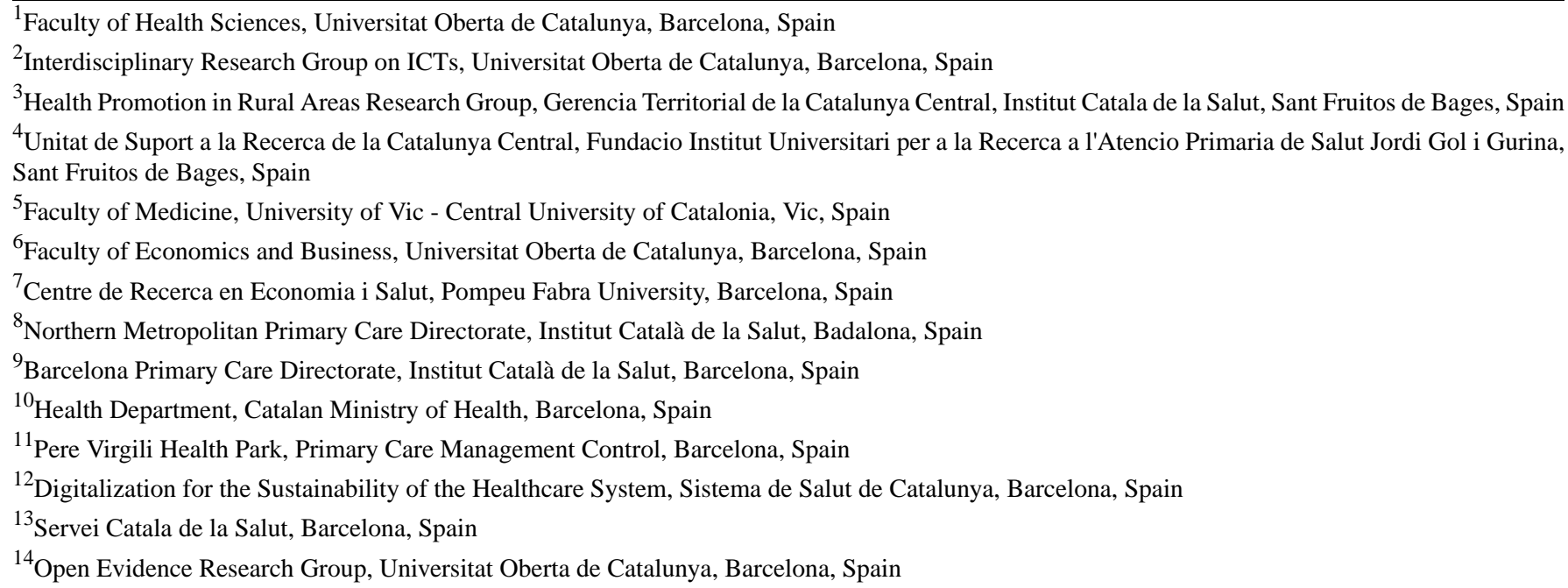

\section{Corresponding Author:}

Josep Vidal-Alaball, MD, MPH, PhD

Health Promotion in Rural Areas Research Group

Gerencia Territorial de la Catalunya Central

Institut Catala de la Salut

Carrer Pica d'Estats, 36

Sant Fruitos de Bages, 08272

Spain

Phone: 346930040

Email: jvidal.cc.ics@gencat.cat

\section{Abstract}

Background: Telemedicine has become a necessary component of clinical practice for the purpose of providing safer patient care during lockdowns due to the COVID-19 pandemic. It has been used to support the health care needs of patients with COVID-19 and routine primary care patients alike. However, this change has not been fully consolidated.

Objective: The objective of this study was to analyze the determinants of health care professionals' intention to use the eConsulta digital clinical consultation tool in the post-COVID-19 context.

Methods: A literature review of the Technology Acceptance Model allowed us to construct a theoretical model and establish a set of hypotheses on the influence of a variety of different factors relating to health care professionals, as well as the institutions where they work, on their intention to use eConsulta. In order to confirm the proposed model, a mixed qualitative and quantitative methodology was used, and a questionnaire was designed to serve as the data collection instrument. The data were analyzed using univariate and bivariate analysis techniques. To confirm the theoretical model, exploratory factor analysis and binary logistic regression were applied. 
Results: The most important variables were related to perceived benefits $(B=2.408)$ and the type of use that individuals habitually made of eConsulta $(B=0.715)$. Environmental pressure $(B=0.678)$, experience with technology $(B=0.542)$, gender $(B=0.639)$, and the degree to which eConsulta had been implemented $(B=0.266)$ were other variables influencing the intention to use the tool in the post-COVID-19 context. When replicating the previous analysis according to professional group, experience with technology and gender in the physician group, and experience with tool use and the center where a professional worked in the nurse group, were found to be of considerable importance.

Conclusions: The implementation and use of eConsulta had increased significantly as a consequence of the COVID-19 pandemic, and the majority of health care professionals were satisfied with its use in practice and planned to incorporate it into their practices in the post-COVID-19 context. Perceived benefits and environmental pressure were determining factors in their attitude toward and intention to use eConsulta.

(J Med Internet Res 2021;23(6):e28944) doi: 10.2196/28944

\section{KEYWORDS}

COVID-19; teleconsultation; eConsultation; eHealth; intention to use; digital health; Technology Acceptance Model; TAM; remote consultation; telemedicine; digital technology; intention; technology assessment; telehealth; pandemic; digital tool

\section{Introduction}

\section{Background}

Lockdowns and social distancing in response to the high rate of COVID-19 transmission have become the main triggers of a challenging digital transformation in many sectors, especially in health care. In this scenario of extreme crisis, the rapid adoption of digital solutions and technological tools has played an important role in the response to the huge pressure on health care systems [1-3]. Telemedicine has become a necessary component of clinical practice for the purpose of providing safer patient care [4,5], and it has been used to support the health care needs of patients with COVID-19 and routine primary care patients alike [6-10].

While the digital transformation in health care has not been as disruptive as the transformations observed in other industries, the spread of COVID-19 seems to have provided a solid and inevitable reason to fully adopt the digital transformation [11]. However, despite the fact that health care services can largely be provided remotely via digital technologies [12], this change has not become fully consolidated [13,14]. This means that further research contributions are still required in relation to the definition and adoption of new digital care models.

To establish telemedicine in routine health care, acceptance by users - health care professionals - is of vital importance to the effective use of technological resources. A variety of factors may explain why a group adopts a specific technological tool to a lesser or greater extent [15]. Of these, social factors are perceived to be the most complex. Legal limitations, patient indifference, lack of remuneration, and uncoordinated implementation by those responsible for formulating policies are weighty arguments explaining stakeholders' refusal to engage $[15,16]$. Some studies have noted that these difficulties may be due to a lack of focus in the implementation of such interventions (ie, health care professionals do not see them as either necessary or effective [17]), or the paucity or inconclusive nature of the studies published thus far [18-20].

To understand whether and how the digital technologies adopted to cope with the COVID-19 crisis will continue to be useful in the postemergency phase-beyond research into outcomes thereof (efficiency, care service quality, etc) — it is necessary to understand the determinants of their use. This paper presents an ex-ante analysis and aims to provide evidence on the determinants of use of the Catalan public health care system's eConsulta tool.

eConsulta, which forms part of a personal health folder [21], is an asynchronous teleconsultation tool available to the 7.5 million inhabitants of Catalonia (located in northeastern Spain) and to its primary care professionals. It was launched in 2015 to complement face-to-face care. The tool's implementation has gradually been extended to the entire primary care network (more than $92 \%$ of primary care teams [PCTs] have used the tool at some point), and it has recently begun to be introduced into the public hospital setting. However, its rate of use up to March 2020 was low compared to face-to-face consultations (just $0.9 \%$ of the total) [22]. Previous studies of telemedicine acceptance by the Catalan public system's health care professionals have suggested that despite being rated positively, especially by nursing staff, the potential technical or organizational disadvantages of the tools were negative predictors of their use [23].

The objective of this study is, therefore, to analyze the determinants of Catalan public primary care professionals' intention to use the eConsulta digital clinical consultation tool in the post-COVID-19 context. These health care professionals (physicians and nurses) work for the Catalan Health Institute (Institut Català de la Salut [ICS]), the main provider of primary care services in Catalonia (providing a $74 \%$ coverage of the Catalan population).

\section{Hypotheses and Model}

Regarding the theoretical approach, the Technology Acceptance Model (TAM) was used [24,25]. Uptake and use of technological applications in the health care area can be formulated as an acceptance intention, and it is therefore possible to take the TAM approach. In TAMs, technology acceptance is considered a determinant of technology use. Hence, health care professionals' acceptance of a digital technology can be considered a determinant of its use [26-30]. Although TAMs have been widely used to explain the use of many different technologies, health care research has shown 
them to be highly suited to analyzing eHealth use. Following the TAM methodology, the proposed model contrasts health care professionals' intention to use a digital tool according to two main dimensions: (1) the perceived benefits of the tool's use and (2) its ease of use. Regarding health care professionals' perceived benefits of the tool, the study distinguishes between those connected with improved efficiency in their care activities (better care management or provision, and time savings or reductions [31,32]), and those connected with improved quality in relation to patients [33]. Regarding ease of use, it has been shown that when a health care professional feels that a technological tool is easy to use and does not require any additional training or specific competencies, the intention to use it clearly increases [34]. Within the specific context of the eConsulta digital tool, the first two research hypotheses are:

\section{H1. The perceived benefits of eConsulta use have an influence on the intention to use it in the post-COVID-19 context. \\ H2. eConsulta's ease of use has an influence on the intention to use it in the post-COVID-19 context.}

However, despite its generalized use for the purpose of corroborating health care professionals' use of digital tools, the TAM methodology has attracted some criticism, mainly stemming from the fact that it does not take into account the influence of other types of external variable that could increase its explanatory power [35,36]. In this respect, various methodological proposals such as the theory of reasoned action and the theory of planned behavior have noted the appropriateness of considering the external influence exerted by health care professionals' close contacts or environment $[37,38]$. In particular, it has been found that patients can exert pressure on a professional by asking him or her to use (or not to use) a tool [39]. Likewise, colleagues and other professional groups working in close collaboration may exert a social influence in relation to the tool's use, either because they are users within the same organizational area or because its use has been directly recommended by them [40,41]. Lastly, the organization in which a professional works can have a direct or indirect influence on the tool's use [29]. Thus, the organization itself can encourage its use by establishing policies and offering training, and by increasing the recognition of, or compensating, those professionals who decide to use it:

\section{H3. Pressure from other groups (patients, health care professionals, the institution's management team) has an influence on the intention to use eConsulta in the post-COVID-19 context.}

A professional's intention to use the tool will also be affected by professional and demographic variables $[42,43]$. Thus, an individual's professional profile (physician or nurse) will determine his or her interest in, and use of, the tool. Specifically, an individual's professional profile determines whether the tool is used to care for patients or to carry out management activities.
This indirectly means that the type of pressure exerted by the environment to ensure a tool is used, and even the perceived benefits and ease of use of the tool, may be different:

\section{H4. The professional profile has an influence on the intention to use eConsulta in the post-COVID-19 context.}

Moreover, the amount of time a professional spends on doing his or her job has an influence on the intention to use the tool. Being older and more professionally experienced may have an influence on the ability or desire to learn about and use technology. Being in a certain occupational category with responsibilities may also have an influence:

\section{H5. An individual's experience as a health care professional has an influence on the intention to use eConsulta in the post-COVID-19 context. \\ H6. A health care professional's age has an influence on the intention to use eConsulta in the post-COVID-19 context.}

Similarly, gender has an influence on the intention to use the tool, mainly because there is a gender bias among professionals. In particular, there is a high percentage of women in the nurse group and, among general practitioners, the distribution of men and women varies as the population gets younger, due to the gradual feminization of the medical profession since the end of the 20th century. By the beginning of the 21 st century, $70 \%$ of all new medical students were women. Since then the figure has risen to $85 \%[44,45]$ :

\section{H7. A health care professional's gender has an influence on the intention to use eConsulta in the post-COVID-19 context.}

Lastly, the health care center where a professional works also determines the intention to use a tool, mainly for reasons of resource availability and management policies at the center:

\section{H8. The health care region or zone in which the health care center where a professional works is located has an influence on the intention to use eConsulta in the post-COVID-19 context. \\ H9. The degree of eConsulta implementation at the health care center where a professional works has an influence on the intention to use it in the post-COVID-19 context. \\ H10. The ease of use of eConsulta (current version) has an influence on the intention to use it in the post-COVID-19 context.}

In summary, we consider that the health care professionals' intention to use the tool in the post-COVID-19 context depends on four main groups of variables: (1) their perception of the tool, (2) external pressure, (3) their profiles, and (4) an additional set of factors linked to the health care center where they work. The proposed model in this regard is shown in Figure 1. 
Figure 1. Proposed model of health care professionals' intention to use the eConsulta tool in the post-COVID-19 context.

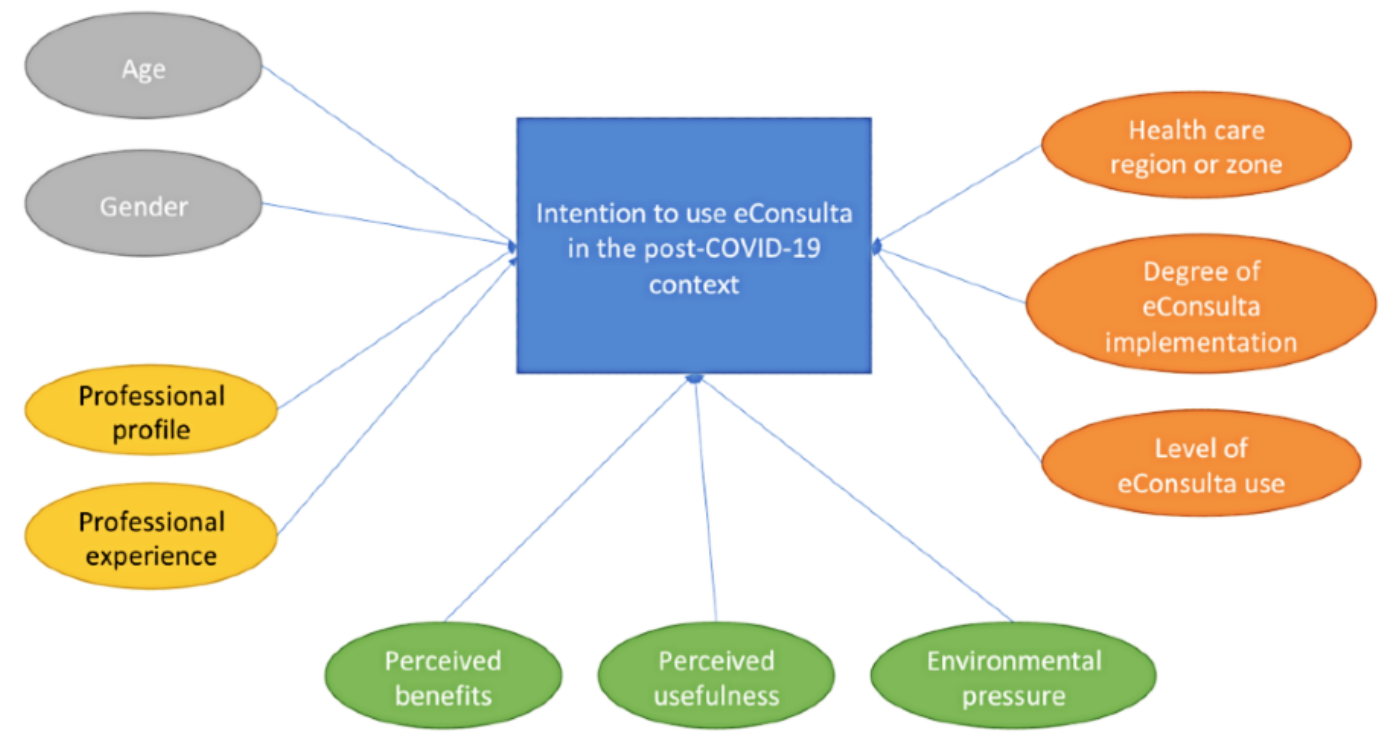

\section{Methods}

\section{Study Design and Sample Selection}

As an exploratory study focusing on the analysis of a single health care institution, a mixed qualitative and quantitative methodology was used, and a questionnaire was designed to serve as the data collection instrument (Multimedia Appendix 1). A review of the literature, together with the health care professionals' experience, served as the basis to create the study variables and the metrics used in the first version of the instrument. The measurement instrument was validated following a pretest.

The final questionnaire was organized into four blocks of questions: (1) sociodemographic and professional background, (2) tool use, (3) tool use motivations, and (4) perceived benefits of tool use.

A health care provider distributed the online questionnaire to physicians, nurses, reproductive and sexual health service staff, social workers, and client care staff working in the ICS's various PCTs across Catalonia. Sample selection was random. The questionnaire was sent to all professionals forming the study universe. Participation was voluntary, and no incentives were offered to fill in and return the questionnaire.

A literature review of TAMs allowed us to establish the theoretical model shown in Figure 1. From this, we derived a set of hypotheses about the influence that a variety of different factors relating to both health care professionals and the institutions where they work has on those professionals' intention to use eConsulta. All the variables shown in the hypotheses, which have an influence on the intention to use eConsulta, are described in Table 1.

The data obtained from the sample of health care professionals were analyzed using SPSS Statistics 20 software (IBM Corp). Univariate and bivariate analysis techniques were used. In order to validate the proposed hypotheses and, therefore, to confirm the theoretical model, several multivariate techniques were applied, such as explanatory factor analysis and binary logistic regression.

The study protocol was approved by the University Institute for Primary Care Research Jordi Gol Healthcare Ethics Committee (code 20/026-P). 
Table 1. Model variables

\begin{tabular}{|c|c|}
\hline Variable & Description \\
\hline $\begin{array}{l}\text { Intention to use eConsulta in the } \\
\text { post-COVID-19 context }\end{array}$ & Dichotomous variable: $0=$ no, $1=$ yes \\
\hline Perceived benefits & $\begin{array}{l}\text { Metric variable indicating a professional's degree of perceived benefit from eConsulta use. This variable } \\
\text { was created using exploratory factor analysis }\end{array}$ \\
\hline Ease of use & $\begin{array}{l}\text { Variable metric indicating the degree of eConsulta's ease of use. This variable was created using ex- } \\
\text { ploratory factor analysis }\end{array}$ \\
\hline Environmental pressure & $\begin{array}{l}\text { Variable metric indicating the degree to which a professional perceives that other agents within his or } \\
\text { her environment (organization, patients, or colleagues) have an influence on his or her use of eConsulta. } \\
\text { This variable was created using exploratory factor analysis }\end{array}$ \\
\hline Professional profile & $\begin{array}{l}\text { Categorical variable indicating an individual's professional profile, where } 1=\text { general practitioner, } \\
2=\text { pediatrician, } 3=\text { family nurse, and } 4=\text { reproductive and sexual health service nurse }\end{array}$ \\
\hline Professional experience & $\begin{array}{l}\text { Categorical variable indicating the amount of time a professional has worked in the health care sector, } \\
\text { where } 1=\text { less than } 1 \text { year, } 2=2-5 \text { years, } 3=6-10 \text { years, } 4=11-20 \text { years, and } 5=\text { more than } 20 \text { years }\end{array}$ \\
\hline Gender & Dichotomous variable indicating an individual's gender: $1=$ man, $2=$ woman \\
\hline Age & $\begin{array}{l}\text { Categorical variable indicating an individual's age range (in years), where } 1=19-29,2=30-39,3=40-49 \text {, } \\
4=50-59 \text {, and } 5=60 \text { or above }\end{array}$ \\
\hline $\begin{array}{l}\text { Health care region or zone in which a pro- } \\
\text { fessional works }\end{array}$ & Categorical variable indicating the health care region or zone in which a professional works \\
\hline Degree of eConsulta implementation & $\begin{array}{l}\text { Categorical variable indicating the degree of eConsulta implementation, where } 1=\text { not yet fully imple- } \\
\text { mented, } 2=\text { fully implemented, and } 3=\text { implemented due to COVID-19 }\end{array}$ \\
\hline Level of eConsulta use & $\begin{array}{l}\text { Categorical variable indicating how eConsulta was used, where } 1=\text { no use, } 2=\text { management use, and } \\
3=\text { management and consultation use }\end{array}$ \\
\hline
\end{tabular}

\section{Results}

The target sample comprised 18,804 health care professionals working in 285 PCTs. The study included responses from 1189 professionals who had agreed to participate between July 6 and July 31,2020 , the period during which the questionnaire was distributed (margin of error $=2.8 \% ; 95 \%, \mathrm{p}=\mathrm{q}=0.05$ ).

\section{Sample Profile}

Regarding age, we found that the majority of the respondents were over 40 years old. The mean age was 48 years. We found that $33.4 \%(n=397)$ were $40-49$ years, and $29.2 \%(n=348)$ were $50-59$ years. It is worth noting that $15.8 \%(\mathrm{n}=188)$ were over 60 years old, and $16.8 \%(\mathrm{n}=200)$ were under 30 years old.

The vast majority of the respondents $(n=944,79.2 \%)$ were women, meaning that just $20.8 \%(n=244)$ were men. In terms of professional profile, $62.2 \%(\mathrm{n}=739)$ were physicians, with various profiles, and $35.2 \%(\mathrm{n}=418)$ were other health care professionals-nurses, matrons, or social care workers. Lastly, just $2.2 \%(n=23)$ fell into the client care staff category.

In relation to the total, and focusing on the physician group, $43.4 \%(\mathrm{n}=515)$ were primary care physicians, and $14.8 \%$ $(\mathrm{n}=175)$ were pediatricians. Regarding the nonphysician health care staff, $26.8 \%(\mathrm{n}=318)$ of the total were nurses and $7.6 \%$ $(n=90)$ were matrons. The majority of these professionals worked in one of three zones of the Barcelona health care region: Metropolitan North $(\mathrm{n}=250,21 \%)$, Barcelona City $(\mathrm{n}=218$, $18.3 \%)$, and Metropolitan South ( $\mathrm{n}=133,11.2 \%)$. Respondents also worked in the health care regions Girona $(n=213,17.9 \%)$ and Catalonia Central $(n=174,14.6 \%)$.
The majority of the respondents had considerable experience as health care professionals. Indeed, $47.4 \%(n=563)$ had over 20 years' experience, and $32.7 \%(n=390)$ had $11-20$ years' experience. Having gained their experience at several centers, just $48 \%$ ( $n=563$ ) stated that they had spent more than 11 years in the same post (more than 20 years: $n=226,19 \% ; 11-20$ years: $\mathrm{n}=354,29.7 \%)$. Of the remaining respondents, $28 \%(\mathrm{n}=333)$ had spent 2-5 years in the same post.

Focusing on the workplace, the degree of eConsulta implementation was quite high. Of the total respondents, $44.9 \%$ $(\mathrm{n}=531)$ indicated that the tool had been fully implemented, and $13.9 \%(n=164)$ reported that it had been largely implemented. It is worth noting that $38.6 \%$ acknowledged that the pace of the tool's implementation had quickened because of COVID-19.

Regarding the respondents' use of eConsulta, it was found that $60.3 \%(n=717)$ had just started using it, and that $26.4 \%(n=314)$ used it regularly and intensively. In fact, $40.5 \% \quad(n=418)$ acknowledged that they used it at least once a week, and $45.8 \%$ $(n=473)$ used it daily. Moreover, the majority of the respondents $(n=828,69.6 \%)$ used it to carry out consultations or to appraise test results and make diagnoses, and $16.9 \% \quad(n=201)$ acknowledged that they used it for management processes only.

Lastly, it should be noted that the impact of COVID-19 on the tool's use was high. Of the total respondents, $38.6 \%(\mathrm{n}=458)$ stated that the tool had been implemented in their workplace. On the other hand, $85.7 \%(n=1018)$ of respondents agreed or strongly agreed with continuing to use it in the post-COVID-19 context. 


\section{Intention to Use eConsulta}

In order to identify the factors that have an influence on eConsulta adoption, a principal component exploratory factor analysis was performed. This statistical technique allows the underlying dimensions, constructs, or latent variables of the variables observed in the study to be explored with greater precision. It was on that basis that we endeavored to explain the process of eConsulta adoption.
The values obtained from the statistical tests carried out showed the suitability of the technique employed (Kaiser-Meyer-Olkin index of sampling adequacy $=0.928$; approximate $\chi^{2}=4122.650$; Bartlett test of sphericity $=171, P<.001$ ) (Table 2). Three factors with an eigenvalue higher than 1 were obtained from the analysis, which in total explained $53 \%$ of the variance. Likewise, it should be noted that the rotation employed in this case was orthogonal (Varimax) because it was deemed that the different factors might not display any correlation.

Table 2. Rotated component matrix. ${ }^{\mathrm{a}}$

\begin{tabular}{|c|c|c|c|}
\hline Original variables & Perceived usefulness & Environmental pressure & $\begin{array}{l}\text { Ease of use (experience with } \\
\text { technology) }\end{array}$ \\
\hline $\begin{array}{l}\text { I feel that eConsulta is useful for managing the calendar } \\
\text { with patients, making it easier to schedule visits at times } \\
\text { that suit them }\end{array}$ & 0.687 & $-{ }^{b}$ & - \\
\hline I feel that it improves the outcomes of my care activities & 0.791 & - & - \\
\hline It allows me to offer patients better treatment & 0.752 & - & - \\
\hline $\begin{array}{l}\text { I talk to other professional colleagues about the benefits of } \\
\text { using eConsulta }\end{array}$ & 0.718 & - & - \\
\hline $\begin{array}{l}\text { eConsulta has been very useful to me during the COVID- } \\
19 \text { pandemic because it has allowed me to care for patients } \\
\text { remotely, thus reducing the risk of infection }\end{array}$ & 0.586 & - & - \\
\hline $\begin{array}{l}\text { I positively rate the potential benefits that eConsulta use } \\
\text { can offer, both for the patients and the } \mathrm{PCT}^{\mathrm{c}} / \text { service }\end{array}$ & 0.815 & - & - \\
\hline I promote eConsulta use among my patients & 0.744 & - & - \\
\hline $\begin{array}{l}\text { As a result of eConsulta implementation in the PCT/service, } \\
\text { ways of working have changed, or new ones have been } \\
\text { introduced, at individual and group levels }\end{array}$ & 0.632 & - & - \\
\hline $\begin{array}{l}\text { The changes made to eConsulta in the COVID-19 pandemic } \\
\text { context have made it easier to use }\end{array}$ & 0.536 & - & - \\
\hline $\begin{array}{l}\text { I feel that eConsulta is very useful for carrying out my } \\
\text { professional activities }\end{array}$ & - & 0.614 & - \\
\hline My colleagues use it often & - & 0.662 & - \\
\hline $\begin{array}{l}\text { The PCT/service that I work in encourages and facilitates } \\
\text { eConsulta use }\end{array}$ & - & 0.514 & - \\
\hline Some of my patients ask me to use it & - & 0.541 & - \\
\hline Care professionals can access eConsulta very easily & - & 0.629 & - \\
\hline Citizens can access eConsulta very easily & - & 0.730 & - \\
\hline $\begin{array}{l}\text { I am a habitual user of technology (both professionally and } \\
\text { personally) }\end{array}$ & - & - & 0.726 \\
\hline $\begin{array}{l}\text { I am a habitual user of social media (both professionally } \\
\text { and personally) }\end{array}$ & - & - & 0.798 \\
\hline I have previous experience using telemedicine systems & - & - & 0.660 \\
\hline Cronbach alpha & 0.916 & 0.819 & 0.747 \\
\hline Eigenvalue & 7.249 & 1.534 & 1.363 \\
\hline Variance explained (\%) & 28.4 & 15.3 & 9.6 \\
\hline
\end{tabular}

${ }^{a}$ Rotation method: Varimax with Kaiser normalization.

${ }^{\mathrm{b}}$ Not applicable.

${ }^{\mathrm{c}}$ PCT: primary care team. 
Three factors emerged from the analysis. The first explained $28.4 \%$ of the variance and included the various benefits of eConsulta use, as observed by the professionals. These benefits referred to improvements in the professionals' relationships with patients and in the efficiency of their work. The second factor explained $15.3 \%$ of the variance and showed the pressure that third parties-work colleagues, patients, or the institution itself-directly or indirectly exerted on the professionals. Lastly, the third factor was perceived ease of use. This factor explained $9.6 \%$ of the variance and showed that some of the professionals who decided to use eConsulta were those who had previous experience of using ICTs (information and communications technologies) (personally) and even telemedicine. A confirmatory factor analysis confirmed the results obtained from the exploratory factor analysis. The results show a goodness of fit (NFI [normed fit index] $=0.897$, CFI [comparative fit index $]=0.906$, TLI [Tucker Lewis index] $=0.870$, RMSEA [root mean square error of approximation] $=0.085$ ).

In order to analyze the influence that these and other factors had on the health care professionals' intention to use eConsulta in the post-COVID-19 context, several logit analyses were performed.

\section{Intention to Use eConsulta in the Post-COVID-19 Context}

The various analyses performed showed the model's goodness of fit (Wald=467.731, $P<.001$; Hosmer-Lemeshow=8.525, $P=.38$ ). Likewise, the model displayed high explanatory power, with a Nagelkerke $\mathrm{R}^{2}$ value of 0.615 .

Regarding the variables in the model, it was found that most of them displayed a direct and significant relationship with the intention to use eConsulta in the post-COVID-19 context (Table $3)$. The most important variables were those referring to perceived benefits $(B=2.408)$ and the type of use that individuals $B=0.715)$. Environmental pressure also contributed to the intention to continue using the tool $(B=0.678)$, as did experience of using technological tools, some of which were specific to the health care area $(B=0.542)$. Lastly, gender had an influence on the intention to use eConsulta $(B=0.639)$, as did the degree of its implementation at the health care center where a professional works $(B=0.266)$.

Table 3. Logistic regression on eConsulta predictors.

\begin{tabular}{|c|c|c|c|c|c|c|}
\hline Variable & $B$ & SE & Wald & $d f$ & $P$ value & $\operatorname{Exp}(B)$ \\
\hline Age & 0.076 & 0.159 & 0.227 & 1 & .63 & 1.079 \\
\hline Gender & 0.639 & 0.308 & 4.303 & 1 & .04 & 1.895 \\
\hline Professional profile & -0.280 & 0.103 & 7.438 & 1 & .006 & 0.755 \\
\hline Health care region or zone in which a professional works & 0.062 & 0.048 & 1.683 & 1 & .20 & 0.940 \\
\hline Professional experience in the health care area & -0.022 & 0.164 & 0.018 & 1 & .89 & 0.978 \\
\hline Benefits & 2.408 & -0.199 & 146.029 & 1 & $<.001$ & 11.113 \\
\hline Environmental pressure & 0.678 & 0.129 & 27.649 & 1 & $<.001$ & 1.971 \\
\hline Ease of use & 0.542 & 0.129 & 17.559 & 1 & $<.001$ & 1.720 \\
\hline Degree of eConsulta implementation & 0.266 & 0.149 & 3.168 & 1 & .08 & 1.304 \\
\hline Level of eConsulta use & 0.715 & 0.176 & 16.469 & 1 & $<.001$ & 2.045 \\
\hline Constant & 0.989 & 0.894 & 1.223 & 1 & .27 & 2.689 \\
\hline
\end{tabular}

The negative value displayed by the profile of the health care professional stands out $(B=-0.280)$. This would suggest that the types of activity that different groups carry out within an organizational area had an influence on the rating of, and the intention to use, eConsulta.

With that in mind, and with the aim of confirming or rejecting all the previously proposed hypotheses contained in the model, we replicated the previous analysis for two groups working in the family medicine area: general practitioners and family nurses (there was a total of 507 general practitioners, of whom $89.7 \%$ $[\mathrm{n}=455]$ used eConsulta and $10.3 \%[\mathrm{n}=52]$ did not. There were 296 nurses, of whom $87.2 \%$ [ $n=258]$ used the tool and $12.8 \%$ $[\mathrm{n}=36]$ did not). Both groups care for adult patients, the majority of whom are advanced in years and are diagnosed with a chronic illness. They are patients whose knowledge and use of ICTs is low.
Considering the different models by group, we found that, among the general practitioner group, all the variables had a direct and positive effect on the intention to use eConsulta. This group was formed by $30.8 \%(n=156)$ men and $69.2 \%(n=351)$ women, with a mean age (in years) between 40 and 59 years (40-49 years: $n=191,37.7 \%$; 50-59 years: $n=151,29.8 \%$ ).

Analyzing Table 4 , the variable with the greatest weight in the model was perceived benefits $(B=2.472)$, followed by gender $(B=1.011)$ and the type of use that individuals made of eConsulta $(B=0.809)$. Regarding type of use, we found that $92.1 \%$ of the physicians made wide use of the tool. Environmental pressure was an important factor in the decision to use it $(B=0.773)$. Lastly, an individual's experience of technology $(B=0.724)$, together with the degree of eConsulta implementation in his or her workplace $(B=0.671)$, also had an influence on the intention to use the tool. 
Table 4. Logistic regression on eConsulta predictors (general practitioners).

\begin{tabular}{|c|c|c|c|c|c|c|}
\hline Variable & $B$ & SE & Wald & $d f$ & $P$ value & $\operatorname{Exp}(B)$ \\
\hline Age & 0.257 & 0.310 & 0.690 & 1 & .41 & 1.293 \\
\hline Gender & 1.011 & 0.485 & 4.353 & 1 & .04 & 2.749 \\
\hline Health care region or zone in which a professional works & 0.066 & 0.096 & 0.482 & 1 & .49 & 1.069 \\
\hline Professional experience in the health care area & 0.118 & 0.290 & 0.166 & 1 & .68 & 1.126 \\
\hline Benefits & 2.472 & 0.330 & 56.054 & 1 & $<.001$ & 11.850 \\
\hline Environmental pressure & 0.773 & 0.221 & 12.190 & 1 & $<.001$ & 2.166 \\
\hline Ease of use & 0.724 & 0.220 & 10.864 & 1 & .001 & 2.062 \\
\hline Degree of eConsulta implementation & 0.671 & 0.332 & 4.085 & 1 & .04 & 1.956 \\
\hline Level of eConsulta use & 0.809 & 0.451 & 3.220 & 1 & .07 & 2.246 \\
\hline Constant & -2.743 & 1.958 & 1.962 & 1 & .16 & 0.064 \\
\hline
\end{tabular}

The family nurse group (Table 5) was formed by $88.6 \%(n=285)$ women, with a mean age between 40 and 59 years (40-49 years: $\mathrm{n}=104,33 \%$; 50-59 years: $\mathrm{n}=95,30 \%)$. Among the variables determining their intention to use eConsulta were, in first place, perceived benefits $(B=2.100)$, followed by the use they make of it $(B=1.362)$. Here, we found that $50.5 \%(n=160)$ stated that they made wide use of the tool, whereas $30 \%(n=96)$ only did so for management purposes (Multimedia Appendix 2). Lastly, environmental pressure was a fundamental factor $(B=0.479)$. It is worth noting that the health care region or zone in which a health care professional works displayed a value of little importance, which was negative in the model $(B=-1.91)$. Of the total cases, $32 \% \quad(n=101)$ and $11.8 \% \quad(n=37)$ of these professionals worked in the health care zones Metropolitan North and Barcelona City, respectively (Multimedia Appendix 3).

Finally, Table 6 shows the significant variables for the three calculated models.
A comparison of the different models shows that, in all of them, perceived benefits was the variable that had the highest explanatory power. After these, in descending order of importance, were experience of eConsulta use and, lastly, the influence that patients, colleagues, and the institution itself had on the professionals. Regarding these variables, it is worth noting the considerable importance that experience with eConsulta use had for the nurse group $(B=1.362)$, compared to the values displayed by this variable in the physician group $(B=0.809)$ or, indeed, in the overall model $(B=0.715)$.

Meanwhile, some variables were significant for the overall model but were not for the partial models. This was the case for experience with technology, which had a value of $B=0.724$ in the physician group but was not significant in the nurse group. The situation regarding the gender variable was similar; in the physician group, the variable was found to be significant and had a high $\mathrm{B}$ value $(B=1.011)$, whereas it was not significant in the nurse group.

Table 5. Logistic regression on eConsulta predictors (nurses).

\begin{tabular}{|c|c|c|c|c|c|c|}
\hline Variable & $B$ & SE & Wald & $d f$ & $P$ value & $\operatorname{Exp}(B)$ \\
\hline Age & -0.293 & 0.316 & 0.860 & 1 & .35 & 0.746 \\
\hline Gender & -0.813 & 0.887 & 0.840 & 1 & .36 & 0.444 \\
\hline Health care region or zone in which a professional works & -0.191 & 0.096 & 4.001 & 1 & .045 & 0.826 \\
\hline Professional experience in the health care area & -0.113 & 0.350 & 0.105 & 1 & .75 & 0.893 \\
\hline Benefits & 2.100 & 0.390 & 29.048 & 1 & $<.001$ & 8.169 \\
\hline Environmental pressure & 0.479 & 0.287 & 2.783 & 1 & .10 & 1.615 \\
\hline Ease of use & 0.161 & 0.255 & 0.397 & 1 & .53 & 1.174 \\
\hline Degree of eConsulta implementation & -0.053 & 0.309 & 0.029 & 1 & .87 & 0.949 \\
\hline Level of eConsulta use & 1.362 & 0.367 & 13.791 & 1 & $<.001$ & 3.906 \\
\hline Constant & 3.747 & 1.909 & 3.851 & 1 & .05 & 42.380 \\
\hline
\end{tabular}


Table 6. Significant variables for the three calculated models.

\begin{tabular}{|c|c|c|c|c|c|c|}
\hline \multirow[t]{2}{*}{ Variable } & \multicolumn{2}{|c|}{ Overall model } & \multicolumn{2}{|c|}{ General practitioners } & \multicolumn{2}{|c|}{ Family nurses } \\
\hline & $B$ & $P$ value & $B$ & $P$ value & $B$ & $P$ value \\
\hline Age & 0.076 & .63 & 0.257 & .41 & -0.293 & .35 \\
\hline Gender & 0.639 & .04 & 1.011 & .04 & -0.813 & .36 \\
\hline Professional profile & -0.280 & .006 & & & & \\
\hline Health care region or zone in which a professional works & 0.062 & .20 & 0.066 & .49 & -0.191 & .045 \\
\hline Professional experience in the health care area & -0.022 & .89 & 0.118 & .68 & -0.113 & .75 \\
\hline Benefits & 2.408 & $<.001$ & 2.472 & $<.001$ & 2.100 & $<.001$ \\
\hline Environmental pressure & 0.678 & $<.001$ & 0.773 & $<.001$ & 0.479 & .10 \\
\hline Ease of use & 0.542 & $<.001$ & 0.724 & .001 & 0.161 & .53 \\
\hline Degree of eConsulta implementation & 0.266 & .08 & 0.671 & .04 & -0.053 & .87 \\
\hline Level of eConsulta use & 0.715 & $<.001$ & 0.809 & .07 & 1.362 & $<.001$ \\
\hline Constant & 0.989 & .27 & -2.743 & .16 & 3.747 & .05 \\
\hline
\end{tabular}

Finally, it should be mentioned that the health care region or Table 8 shows the hypotheses that were confirmed or rejected zone in which a professional works was a variable that displayed for each of the three models. a negative effect on the nurse group's intention to use eConsulta (Table 7).

Table 7. Distribution of the family nurse group by health care region or zone.

\begin{tabular}{lll}
\hline Health care region or zone & Nurses, $\mathrm{n}(\%)$ & Cumulative $\%$ \\
\hline Metropolitan North & $45(15.2)$ & 15.2 \\
Central Catalonia & $39(13.1)$ & 28.3 \\
Barcelona City & $56(18.9)$ & 47.1 \\
Lleida & $12(4.0)$ & 51.2 \\
Metropolitan South & $38(12.8)$ & 64.0 \\
Girona & $58(19.5)$ & 83.5 \\
Camp de Tarragona & $24(8.1)$ & 91.6 \\
Terres de l'Ebre & $25(8.4)$ & 100.0 \\
Total & $297(100.0)$ & $-{ }^{a}$ \\
\hline
\end{tabular}

${ }^{\mathrm{a}}$ Not applicable. 
Table 8. Hypotheses and results.

\begin{tabular}{|c|c|c|c|}
\hline Hypotheses & Overall model & Physicians & Nurses \\
\hline $\begin{array}{l}\text { H1. The perceived benefits of eConsulta use have an influence on the intention to use it in the } \\
\text { post-COVID-19 context. }\end{array}$ & Yes & Yes & Yes \\
\hline H2. eConsulta's ease of use has an influence on the intention to use it in the post-COVID-19 context. & Yes & Yes & No \\
\hline $\begin{array}{l}\text { H3. Pressure from other groups (patients, health care professionals, the institution's management team) } \\
\text { has an influence on the intention to use eConsulta in the post-COVID-19 context. }\end{array}$ & Yes & Yes & Yes \\
\hline $\begin{array}{l}\text { H4. The professional profile has an influence on the intention to use eConsulta in the post-COVID-19 } \\
\text { context. }\end{array}$ & Yes & $-^{\mathrm{a}}$ & - \\
\hline $\begin{array}{l}\text { H5. An individual's experience as a health care professional has an influence on the intention to use } \\
\text { eConsulta in the post-COVID-19 context. }\end{array}$ & No & No & No \\
\hline $\begin{array}{l}\text { H6. A health care professional's age has an influence on the intention to use eConsulta in the post-COVID- } \\
19 \text { context. }\end{array}$ & Yes & No & No \\
\hline $\begin{array}{l}\text { H7. A health care professional's gender has an influence on the intention to use eConsulta in the } \\
\text { post-COVID-19 context. }\end{array}$ & Yes & Yes & No \\
\hline $\begin{array}{l}\text { H8. The health care region or zone in which the health care center where a professional works is located } \\
\text { has an influence on the intention to use eConsulta in the post-COVID-19 context. }\end{array}$ & No & No & Yes \\
\hline $\begin{array}{l}\text { H9. The degree of eConsulta implementation at the health care center where a professional works has } \\
\text { an influence on the intention to use it in the post-COVID-19 context. }\end{array}$ & Yes & Yes & No \\
\hline $\begin{array}{l}\text { H10. The ease of use of eConsulta (current version) has an influence on the intention to use it in the } \\
\text { post-COVID-19 context. }\end{array}$ & Yes & Yes & Yes \\
\hline
\end{tabular}

${ }^{\mathrm{a}}$ Not applicable.

\section{Discussion}

\section{Principal Findings}

The objective of this study was to identify the factors that have an influence on eConsulta adoption, and the influence of these and other factors on the intention to use the tool in the post-COVID-19 context. To that end, a theoretical model based on a modified TAM was used as the analysis tool.

eConsulta has become a key tool for providing remote medical care owing to the challenges posed by the COVID-19 pandemic. The use of this tool has increased significantly since the start of the pandemic, and the majority of health care professionals are now able to consider using it in their routine medical practice, even after the relaxation of social distancing measures and a return to some degree of normality. We focused our research on forecasts for tool use in the post-COVID-19 context because, as soon as social distancing measures are removed, it is likely that professionals will have the option to choose how, that is, by which means, they connect with their patients. This possibility to choose, which is not feasible while social distancing measures are in place, is very significant, not only from the perspective of analyzing the explanatory factors of eConsulta use, but also from the perspective of health policies. With the experience of its mass use during lockdown, we analyzed explanatory factors for the future use of the tool within the context of a greater freedom of choice. The purpose of doing so was to find out whether the lockdowns had changed the factors driving the use of digital tools for the provision of medical care or, conversely, whether the health care professionals perceived such use to be exceptional, with their preferences being more aligned with a return to the prepandemic situation. These results are undoubtedly very useful for the design of public policies on health care delivery via digital technologies.

Our study confirms, as previous studies have done [5], that perceived usefulness was the explanatory factor with the biggest effect on the attitude toward and intention to use eConsulta in the post-COVID-19 context. As the TAM suggests, the significance of this determining factor refers back to the importance of perceived usefulness when the use of a technology needs to be explained [46,47]. Specifically, ICS health care professionals placed importance on improved patient relationships and the efficiency of their work in their intention to use the tool, and on perceived benefits in their intention to use the tool in the post-COVID-19 context. In this respect, several studies have shown that telecare reduces the number of low value-added face-to-face visits, thus providing evidence to support intervention efficiency from the health care provider's viewpoint $[48,49]$. It is therefore crucial for the health care system's best way of operating to be accepted by the professionals working within it.

The next most important variable was the type of use that individuals habitually made of eConsulta. Bearing in mind that the core work of physicians is patient care, whereas that of the nurse group involves either management or carrying out tasks related to communicating with, and sending information to, patients, an increase in perceived usefulness by the latter positively influenced their attitude toward, and increased their intention to use, the tool. This is consistent with many studies on the acceptance of telemedicine solutions by both primary care providers [50] and nursing staff [51].

Perceived ease of use also had a positive impact on the attitude toward using eConsulta, in particular on improving some professionals' attitude toward and intention to use it because 
they felt that it would not involve any effort; this was especially so in the physician group [30,52]. As seen in previous studies, general practitioners with prior experience in digital health care technologies were more enthusiastic and optimistic than those who had yet to use it $[19,49]$. Despite the evidence showing that as knowledge of ICT use increases, the difficulties an individual encounters when using it decrease [53], it is worth noting the little weight that this factor had compared to benefits and environmental pressure. This might be due to either the generalized implementation of this tool by the administration or the rapid digital transformation that this sector has experienced as a consequence of COVID-19. However, experience using technological tools was a variable displaying a direct and significant relationship with the intention to use eConsulta in the post-COVID-19 context. This result highlights the importance of developing staff's competencies for the sustainable adoption of digital solutions in the health care field.

Second in order of importance in the explanation of the tool's use by ICS health care professionals was the pressure that third parties-work colleagues, patients, or the institution itself-directly or indirectly exerted on them. Environmental pressure also contributed to the intention to continue using eConsulta in the post-COVID-19 context. In this respect, we found that when patients had easy access to the tool, it made them ask health care professionals to use it. Access to the personal health folder, a tool that enables citizens to securely access their personal information and online services [54,55], was key. Similarly, the fact that some colleagues rated the tool positively, or actually used it, also had a direct influence on the intention to use it. This could also be attributed to network effects, which are crucial to the adoption of any technology [56]. Lastly, the fact that the health care institution itself had committed to eConsulta implementation was an important reason for adopting it.

Finally, it should be noted that the degree of eConsulta implementation at the health care center where a professional works had an influence on the intention to use it in the post-COVID-19 context, especially among the physician group. This might be due to the fact that the tool's implementation differed at each health care center. Regarding nursing staff, a plausible explanation as to why it did not affect them is that each health care region or zone is independent in terms of the types of activity (patient treatment or management) that the nurse group carries out, so the types of use made of the tool differs. In fact, the nurse group was the most reticent in terms of the continued use of the tool in the postlockdown phase. Research into the implications of eHealth and telemedicine on professional practice has repeatedly shown that implementation of digital practices for the provision of medical care leads to significant changes in the tasks that professionals carry out. For a sustainable eConsulta implementation, the tasks that the physician and nurse groups carry out will undoubtedly need to be reviewed to ensure that the provision of value-added health care is more efficient and of higher quality.
The COVID-19 pandemic has led to the implementation of digital solutions at record speed and with unprecedented impact. The experience that this has provided nurses and physicians with increases the likelihood of them continuing to use it in the post-COVID-19 context. It is worth taking advantage of the impetus that the current crisis has given us to implement at least some of the solutions proposed in the scientific literature. This study's data cannot be extrapolated to other health care systems; however, the results are critical for digital health care policy planners because the success of eConsulta will largely depend on whether health care professionals promote it. In any case, maintaining the drivers of a continued use of digital tools for the provision of medical care must go hand in hand with practices that promote their use by patients. Having professional groups that are active and ready for the digital transformation is of little use if, on the care services demand side, patients continue to opt for face-to-face care as a matter of preference. In this respect, it is important to make further advances in relation to the social dissemination of the strengths of social health care tools, while at the same time putting efforts into reducing their weaknesses, especially the care inequalities that their use may generate.

\section{Limitations}

This study has a number of potential limitations. First, it is a survey-based study, subject to the bias response rates that are inherent to all studies based on data of this type. Second, the survey we used was new and unvalidated, utilized to determine eConsulta use by health care professionals. It is our belief, however, that the survey questions posed were of a pragmatic nature, and that the answers faithfully reflected the sentiments of all the groups. Lastly, the survey was administered in less than 1 month in the midst of drastic changes to medical practice brought about by the pandemic, so opinions and preferences may continue to evolve. Notwithstanding the above, we believe that the sample size analyzed and the degree of statistical significance observed together make our results robust.

\section{Conclusions}

The implementation and use of eConsulta had increased significantly as a consequence of the COVID-19 pandemic, and the majority of the health care professionals were satisfied with its use in practice and planned to incorporate it into their practices in the post-COVID-19 context. Perceived benefits and environmental pressures were determining factors in the attitude toward and intention to use eConsulta. However, some reticence in terms of the continued use of the tool in the post-COVID-19 context was detected, especially among the nurse group. For this digital transformation in health care to continue beyond the pandemic, it is important to establish connections between health care professionals' use of the tool on one hand and modification of their tasks on the other, and thus improve the quality of their care. In addition, patients must be educated to use the tool more proficiently.

\section{Conflicts of Interest}

None declared. 


\section{Multimedia Appendix 1}

Correlation matrix between variables: overall model.

[DOCX File, 22 KB-Multimedia Appendix 1]

\section{Multimedia Appendix 2}

Tool use by group.

[DOCX File, 17 KB-Multimedia Appendix 2]

\section{Multimedia Appendix 3}

Health care region or zone by group.

[DOCX File, 23 KB-Multimedia Appendix 3]

\section{References}

1. Sterling R, LeRouge C. On-Demand Telemedicine as a Disruptive Health Technology: Qualitative Study Exploring Emerging Business Models and Strategies Among Early Adopter Organizations in the United States. J Med Internet Res 2019 Nov 15;21(11):e14304 [FREE Full text] [doi: 10.2196/14304] [Medline: $\underline{31730038]}$

2. Hollander JE, Carr BG. Virtually Perfect? Telemedicine for Covid-19. N Engl J Med 2020 Apr 30;382(18):1679-1681. [doi: 10.1056/NEJMp2003539] [Medline: $\underline{\text { 32160451] }}$

3. Mahmood S, Hasan K, Colder Carras M, Labrique A. Global Preparedness Against COVID-19: We Must Leverage the Power of Digital Health. JMIR Public Health Surveill 2020 Apr 16;6(2):e18980 [FREE Full text] [doi: 10.2196/18980] [Medline: $\underline{\text { 32297868] }}$

4. Calton B, Abedini N, Fratkin M. Telemedicine in the Time of Coronavirus. J Pain Symptom Manage 2020 Jul;60(1):e12-e14 [FREE Full text] [doi: 10.1016/j.jpainsymman.2020.03.019] [Medline: $\underline{\text { 32240756] }}$

5. Vidal-Alaball J, Acosta-Roja R, Pastor Hernández N, Sanchez Luque U, Morrison D, Narejos Pérez S, et al. Telemedicine in the face of the COVID-19 pandemic. Aten Primaria 2020 Jun;52(6):418-422 [FREE Full text] [doi:

10.1016/j.aprim.2020.04.003] [Medline: 22402477 ]

6. Greenhalgh T, Koh GCH, Car J. Covid-19: a remote assessment in primary care. BMJ 2020 Mar 25;368:m1182. [doi: 10.1136/bmj.m1182] [Medline: 32213507]

7. Greenhalgh T, Wherton J, Shaw S, Morrison C. Video consultations for covid-19. BMJ 2020 Mar 12;368:m998. [doi: 10.1136/bmj.m998] [Medline: 32165352]

8. Triana AJ, Gusdorf RE, Shah KP, Horst SN. Technology Literacy as a Barrier to Telehealth During COVID-19. Telemed J E Health 2020 Sep 01;26(9):1118-1119. [doi: 10.1089/tmj.2020.0155] [Medline: 32429770]

9. Smith AC, Thomas E, Snoswell CL, Haydon H, Mehrotra A, Clemensen J, et al. Telehealth for global emergencies: Implications for coronavirus disease 2019 (COVID-19). J Telemed Telecare 2020 Mar 20;26(5):309-313. [doi: $10.1177 / 1357633 \times 20916567]$

10. Pérez Sust P, Solans O, Fajardo JC, Medina Peralta M, Rodenas P, Gabaldà J, et al. Turning the Crisis Into an Opportunity: Digital Health Strategies Deployed During the COVID-19 Outbreak. JMIR Public Health Surveill 2020 May 04;6(2):e19106 [FREE Full text] [doi: 10.2196/19106] [Medline: $\underline{\text { 32339998] }}$

11. Golinelli D, Boetto E, Carullo G, Nuzzolese AG, Landini MP, Fantini MP. Adoption of Digital Technologies in Health Care During the COVID-19 Pandemic: Systematic Review of Early Scientific Literature. J Med Internet Res 2020 Nov 06;22(11):e22280 [FREE Full text] [doi: 10.2196/22280] [Medline: 33079693]

12. Keesara S, Jonas A, Schulman K. Covid-19 and Health Care's Digital Revolution. N Engl J Med 2020 Jun 04;382(23):e82 [FREE Full text] [doi: 10.1056/nejmp2005835]

13. Herrmann M, Boehme P, Mondritzki T, Ehlers JP, Kavadias S, Truebel H. Digital Transformation and Disruption of the Health Care Sector: Internet-Based Observational Study. J Med Internet Res 2018 Mar 27;20(3):e104 [FREE Full text] [doi: 10.2196/jmir.9498] [Medline: 29588274]

14. Perakslis ED. Strategies for delivering value from digital technology transformation. Nat Rev Drug Discov 2017 Feb;16(2):71-72. [doi: 10.1038/nrd.2016.265] [Medline: 28082744]

15. Choi WS, Park J, Choi JYB, Yang J. Stakeholders' resistance to telemedicine with focus on physicians: Utilizing the Delphi technique. J Telemed Telecare 2019 Jul 01;25(6):378-385. [doi: 10.1177/1357633X18775853] [Medline: 29792080]

16. Scott Kruse C, Karem P, Shifflett K, Vegi L, Ravi K, Brooks M. Evaluating barriers to adopting telemedicine worldwide: A systematic review. J Telemed Telecare 2018 Jan;24(1):4-12 [FREE Full text] [doi: 10.1177/1357633X16674087] [Medline: 29320966]

17. Farr M, Banks J, Edwards HB, Northstone K, Bernard E, Salisbury C, et al. Implementing online consultations in primary care: a mixed-method evaluation extending normalisation process theory through service co-production. BMJ Open 2018 Dec 19;8(3):e019966 [FREE Full text] [doi: 10.1136/bmjopen-2017-019966] [Medline: 29555817] 
18. Atherton H, Brant H, Ziebland S, Bikker A, Campbell J, Gibson A, et al. The potential of alternatives to face-to-face consultation in general practice, and the impact on different patient groups: a mixed-methods case study. Health Serv Deliv Res 2018 Jun;6(20):1-200. [doi: 10.3310/hsdr06200] [Medline: 29889485]

19. McGrail KM, Ahuja MA, Leaver CA. Virtual Visits and Patient-Centered Care: Results of a Patient Survey and Observational Study. J Med Internet Res 2017 May 26;19(5):e177 [FREE Full text] [doi: 10.2196/jmir.7374] [Medline: 28550006]

20. WHO Guideline: Recommendations on Digital Interventions for Health System Strengthening. World Health Organization. 2019. URL: https://apps.who.int/iris/bitstream/handle/10665/311941/9789241550505-eng.pdf?ua=1 [accessed 2021-01-17]

21. Saigí F, Cerdá Calafat I, Guanyabens Calvet J, Carrau Vidal E. [Personal health records: the case of the Personal Health Folder of Catalonia (Spain)]. Gac Sanit 2012 Nov;26(6):582-584 [FREE Full text] [doi: 10.1016/j.gaceta.2012.03.005] [Medline: 22554458]

22. Fernández OS, Seguí FL, Vidal-Alaball J, Bonet Simo JM, Vian OH, Cabo PR, et al. Primary Care Doctor Characteristics That Determine the Use of Teleconsultations in the Catalan Public Health System: Retrospective Descriptive Cross-Sectional Study. JMIR Med Inform 2020 Jan 31;8(1):e16484 [FREE Full text] [doi: 10.2196/16484] [Medline: 32012061]

23. Vidal-Alaball J, López Seguí F, Garcia Domingo JL, Flores Mateo G, Sauch Valmaña G, Ruiz-Comellas A, et al. Primary Care Professionals' Acceptance of Medical Record-Based, Store and Forward Provider-to-Provider Telemedicine in Catalonia: Results of a Web-Based Survey. Int J Environ Res Public Health 2020 Jun 08;17(11):4092 [FREE Full text] [doi: 10.3390/ijerph17114092] [Medline: 32521740]

24. Davis FD. Perceived Usefulness, Perceived Ease of Use, and User Acceptance of Information Technology. MIS Quarterly 1989 Sep;13(3):319. [doi: 10.2307/249008]

25. Davis FD. A technology acceptance model for empirically testing new end-user information systems? Theory and results. Massachusetts Institute of Technology. 1985. URL: https://dspace.mit.edu/handle/1721.1/15192 [accessed 2020-11-15]

26. Ducey AJ, Coovert MD. Predicting tablet computer use: An extended Technology Acceptance Model for physicians. Health Policy and Technology 2016 Sep;5(3):268-284. [doi: 10.1016/j.hlpt.2016.03.010]

27. Tao D, Shao F, Wang H, Yan M, Qu X. Integrating usability and social cognitive theories with the technology acceptance model to understand young users' acceptance of a health information portal. Health Informatics J 2020 Jun 11;26(2):1347-1362 [FREE Full text] [doi: 10.1177/1460458219879337] [Medline: 31603378]

28. Lacasta Tintorer D, Flayeh Beneyto S, Manresa JM, Torán-Monserrat P, Jiménez-Zarco A, Torrent-Sellens J, et al. Understanding the discriminant factors that influence the adoption and use of clinical communities of practice: the ECOPIH case. BMC Health Serv Res 2015 Sep 10;15(1):373 [FREE Full text] [doi: 10.1186/s12913-015-1036-4] [Medline: 26358037]

29. Saigi-Rubió F, Jiménez-Zarco A, Torrent-Sellens J. Determinants of the intention to use telemedicine: Evidence from primary care physicians. Int J Technol Assess Health Care 2016 Jul 29;32(1-2):29-36. [doi: 10.1017/s0266462316000015]

30. Saigí-Rubió F, Torrent-Sellens J, Jiménez-Zarco A. Drivers of telemedicine use: comparative evidence from samples of Spanish, Colombian and Bolivian physicians. Implement Sci 2014 Oct 08;9(1):128 [FREE Full text] [doi:

10.1186/s13012-014-0128-6] [Medline: 25293651]

31. Chaudhry B, Wang J, Wu S, Maglione M, Mojica W, Roth E, et al. Systematic review: impact of health information technology on quality, efficiency, and costs of medical care. Ann Intern Med 2006 May 16;144(10):742-752 [FREE Full text] [doi: 10.7326/0003-4819-144-10-200605160-00125] [Medline: 16702590]

32. Jennett PA, Affleck Hall L, Hailey D, Ohinmaa A, Anderson C, Thomas R, et al. The socio-economic impact of telehealth: a systematic review. J Telemed Telecare 2003 Dec;9(6):311-320. [doi: 10.1258/135763303771005207] [Medline: 14680514]

33. Kamal SA, Shafiq M, Kakria P. Investigating acceptance of telemedicine services through an extended technology acceptance model (TAM). Technology in Society 2020 Feb;60:101212. [doi: 10.1016/j.techsoc.2019.101212]

34. Kissi J, Dai B, Dogbe CS, Banahene J, Ernest O. Predictive factors of physicians' satisfaction with telemedicine services acceptance. Health Informatics J 2020 Sep 19;26(3):1866-1880 [FREE Full text] [doi: 10.1177/1460458219892162] [Medline: $\underline{31854222]}$

35. Bagozzi R. The Legacy of the Technology Acceptance Model and a Proposal for a Paradigm Shift. JAIS 2007 Apr;8(4):244-254. [doi: 10.17705/1jais.00122]

36. Lee SY, Lee K. Factors that influence an individual's intention to adopt a wearable healthcare device: The case of a wearable fitness tracker. Technological Forecasting and Social Change 2018 Apr;129:154-163. [doi: 10.1016/j.techfore.2018.01.002]

37. Schepers J, Wetzels M. A meta-analysis of the technology acceptance model: Investigating subjective norm and moderation effects. Information \& Management 2007 Jan;44(1):90-103. [doi: 10.1016/j.im.2006.10.007]

38. Gong Z, Han Z, Li X, Yu C, Reinhardt JD. Factors Influencing the Adoption of Online Health Consultation Services: The Role of Subjective Norm, Trust, Perceived Benefit, and Offline Habit. Front Public Health 2019 Oct 4;7:286 [FREE Full text] [doi: 10.3389/fpubh.2019.00286] [Medline: 31637229]

39. Almathami HKY, Win KT, Vlahu-Gjorgievska E. Barriers and Facilitators That Influence Telemedicine-Based, Real-Time, Online Consultation at Patients' Homes: Systematic Literature Review. J Med Internet Res 2020 Feb 20;22(2):e16407 [FREE Full text] [doi: 10.2196/16407] [Medline: $\underline{\text { 32130131] }}$

40. Erickson SM, Rockwern B, Koltov M, McLean RM, Medical Practice Quality Committee of the American College of Physicians. Putting Patients First by Reducing Administrative Tasks in Health Care: A Position Paper of the American 
College of Physicians. Ann Intern Med 2017 May 02;166(9):659-661 [FREE Full text] [doi: 10.7326/M16-2697] [Medline: 28346948]

41. Liu S, Reese TJ, Kawamoto K, Del Fiol G, Weir C. A systematic review of theoretical constructs in CDS literature. BMC Med Inform Decis Mak 2021 Mar 17;21(1):102 [FREE Full text] [doi: 10.1186/s12911-021-01465-2] [Medline: 33731089]

42. Zhang X, Han X, Dang Y, Meng F, Guo X, Lin J. User acceptance of mobile health services from users' perspectives: The role of self-efficacy and response-efficacy in technology acceptance. Inform Health Soc Care 2017 Mar 26;42(2):194-206. [doi: 10.1080/17538157.2016.1200053] [Medline: 27564428]

43. Taylor D, Bury N, Campling N, Carter S, Garfied S, Newbould J, et al. A Review of the use of the Health Belief Model (HBM), the Theory of Reasoned Action (TRA), the Theory of Planned Behaviour (TPB) and the Trans-Theoretical Model (TTM) to study and predict health related behaviour change. Department of Health, National Institute for Health and Clinical Excellence. 2007 Feb. URL: https://warwick.ac.uk/fac/sci/med/study/ugr/mbchb/phase1 08/semester2/healthpsychology/ nice-doh draft review of health behaviour theories.pdf [accessed 2020-11-15]

44. Arrizabalaga P, Bruguera M. [The feminization and the profession of Medicine]. Med Clin (Barc) 2009 Jul 04;133(5):184-186. [doi: 10.1016/j.medcli.2009.01.027] [Medline: 19426998$]$

45. Paik JE. The Feminization of Medicine. JAMA 2000 Feb 02;283(5):666. [doi: 10.1001/jama.283.5.666-jms0202-2-1]

46. Marangunić N, Granić A. Technology acceptance model: a literature review from 1986 to 2013. Univ Access Inf Soc 2014 Feb 16;14(1):81-95. [doi: 10.1007/s10209-014-0348-1]

47. Saigi-Rubió F, Jiménez-Zarco A, Torrent-Sellens J. Determinants of the intention to use telemedicine: Evidence from primary care physicians. Int J Technol Assess Health Care 2016 Jul 29;32(1-2):29-36. [doi: 10.1017/s0266462316000015]

48. López Seguí F, Walsh S, Solans O, Adroher Mas C, Ferraro G, García-Altés A, et al. Teleconsultation Between Patients and Health Care Professionals in the Catalan Primary Care Service: Message Annotation Analysis in a Retrospective Cross-Sectional Study. J Med Internet Res 2020 Sep 17;22(9):e19149 [FREE Full text] [doi: 10.2196/19149] [Medline: $\underline{32687477]}$

49. López Seguí F, Vidal-Alaball J, Sagarra Castro M, García-Altés A, García Cuyàs F. General Practitioners' Perceptions of Whether Teleconsultations Reduce the Number of Face-to-face Visits in the Catalan Public Primary Care System: Retrospective Cross-Sectional Study. J Med Internet Res 2020 Mar 16;22(3):e14478 [FREE Full text] [doi: 10.2196/14478] [Medline: 32175914]

50. Tudiver F, Wolff LT, Morin PC, Teresi J, Palmas W, Starren J, et al. Primary care providers' perceptions of home diabetes telemedicine care in the IDEATel project. J Rural Health 2007 Jan;23(1):55-61. [doi: 10.1111/j.1748-0361.2006.00068.x] [Medline: 17300479 ]

51. Mullen-Fortino M, DiMartino J, Entrikin L, Mulliner S, Hanson CW, Kahn JM. Bedside nurses' perceptions of intensive care unit telemedicine. Am J Crit Care 2012 Jan 31;21(1):24-31; quiz 32. [doi: 10.4037/ajcc2012801] [Medline: 22210696]

52. Idoga PE, Toycan M, Nadiri H, Çelebi E. Assessing factors militating against the acceptance and successful implementation of a cloud based health center from the healthcare professionals' perspective: a survey of hospitals in Benue state, northcentral Nigeria. BMC Med Inform Decis Mak 2019 Feb 19;19(1):34 [FREE Full text] [doi: 10.1186/s12911-019-0751-x] [Medline: $\underline{30782166]}$

53. Kalayou MH, Endehabtu BF, Tilahun B. The Applicability of the Modified Technology Acceptance Model (TAM) on the Sustainable Adoption of eHealth Systems in Resource-Limited Settings. JMDH 2020 Dec;Volume 13:1827-1837. [doi: 10.2147/jmdh.s284973]

54. Model d'Atenció No Presencial en el Sistema Sanitari de Catalunya. Departament de Salut, Barcelona. 2014. URL: http:/ /salutweb.gencat.cat/web/.content/ ambits-actuacio/Linies-dactuacio/model assistencial/MANP2013 2016.pdf [accessed 2021-06-09]

55. La Meva Salut (Personal Health Folder). URL: https://lamevasalut.gencat.cat/ [accessed 2021-06-09]

56. Torrent-Sellens J. Knowledge Products and Network Externalities: Implications for the Business Strategy. J Knowl Econ 2012 Nov 8;6(1):138-156. [doi: 10.1007/s13132-012-0122-7]

\section{Abbreviations}

CFI: comparative fit index

ICS: Institut Català de la Salut

ICT: information and communications technology

NFI: normed fit index

PCT: primary care team

RMSEA: root mean square error of approximation

TAM: Technology Acceptance Model

TLI: Tucker Lewis index 
Edited by C Basch; submitted 19.03.21; peer-reviewed by E van der Velde, S Liu; comments to author 14.04.21; revised version received 18.05.21; accepted 31.05.21; published 24.06.21

Please cite as:

Saigí-Rubió F, Vidal-Alaball J, Torrent-Sellens J, Jiménez-Zarco A, López Segui F, Carrasco Hernandez, M, Alzaga Reig X, Bonet Simó JM, Abizanda González M, Piera-Jimenez J, Solans $O$

Determinants of Catalan Public Primary Care Professionals' Intention to Use Digital Clinical Consultations (eConsulta) in the Post-COVID-19 Context: Mixed Methods Study

J Med Internet Res 2021;23(6):e28944

URL: https://www.jmir.org/2021/6/e28944/

doi: $10.2196 / 28944$

PMID:

CFrancesc Saigí-Rubió, Josep Vidal-Alaball, Joan Torrent-Sellens, Ana Jiménez-Zarco, Francesc López Segui, Marta Carrasco Hernandez, Xavier Alzaga Reig, Josep Maria Bonet Simó, Mercedes Abizanda González, Jordi Piera-Jimenez, Oscar Solans. Originally published in the Journal of Medical Internet Research (https://www.jmir.org), 24.06.2021. This is an open-access article distributed under the terms of the Creative Commons Attribution License (https://creativecommons.org/licenses/by/4.0/), which permits unrestricted use, distribution, and reproduction in any medium, provided the original work, first published in the Journal of Medical Internet Research, is properly cited. The complete bibliographic information, a link to the original publication on https://www.jmir.org/, as well as this copyright and license information must be included. 